\title{
ДИСкУСії
}

Klinichna khirurhiia. 2018 May;85(5):63-65.

DOI: $10.26779 / 2522-1396.2018 .05 .63$

УДК 616-008.9:621.791.052

\section{Дискуссионные вопросы высокочастотной электросварки биологических тканей}

\section{П. Ф. Музыченко ${ }^{1}$, В. А. Черняк ${ }^{1}$, Ю. Н. Ланкин ${ }^{2}$, Н. Н. Эргард ${ }^{1}$, Р. А. Хохлова ${ }^{3}$ \\ ${ }^{1}$ Национальный медицинский университет имени А. А. Богомольца, г. Киев, \\ ${ }^{2}$ Институт электросварки имени Е. О. Патона НАН Украины, г. Киев, \\ ${ }^{3}$ Национальный технический университет Украины \\ «Киевского политехнического института имени Игоря Сикорского», г. Киев \\ The discussion issues in a high frequency electric welding of biological tissues}

\author{
P. F. Muzychenko ${ }^{1}$, V. A. Chernyak ${ }^{1}$, Yu. N. Lankin ${ }^{2}$, N. M. Ergard ${ }^{1}$, R. A. Khokhlova ${ }^{3}$ \\ ${ }^{1}$ Bogomolets National Medical University, Kyiv, \\ ${ }^{2}$ E.O. Paton Electric Welding Institute, Kyiv, \\ ${ }^{3}$ National Technical University of Ukraine «Igor Sikorsky Kyiv Polytechnic Institute», Kiev
}

\section{Реферат}

Цель. Исследование физических свойств составляющих биологических тканей и их роли в процессе электрической сварки мягких биологических тканей, а также измерение температуры в зоне электросварки.

Материалы и методы. Исследования провели с использованием созданной системы для измерения температуры, состоящей из усилителя термо-ЭДС, внешнего модуля АЦП Е14-440 “Л-Кард”, ноутбука с программным обеспечением “PowerGraph”. Использовали также биполярный электрохирургический зажим и ВЧ-электрокоагулятор ЕК-300М1. Для имеющегося при сварке биологических тканей диапазона температур 40 - $200{ }^{\circ} \mathrm{C}$ выбраны термопары К-типа диаметром 70 мкм.

Результаты. Проведенные исследования позволили установить, что сопротивление электролитов уменышается, а проводимость - увеличивается с повышением температуры. Это объясняется тем, что с повышением температуры для слабых растворов увеличивается их диссоциация и, следовательно, число положительных и отрицательных ионов. Электропроводность цельных органов в 2 - 5 раз ниже, чем электропроводность биологических жидкостей. Поэтому при «полном» обезвоживании ткань практически теряет электропроводность, тепло в ней перестает выделяться и происходит резкое падение напряжения, силы тока и сопротивления, что предотвращает глубокие деструктивные изменения мягких тканей в зоне электросварки. Эти данные получены нами в процессе выполнения эксперимента по изучению температурных режимов тканей кишечника, мышечной ткани, легкого и печени.

Выводы. Данными, полученными в ходе выполнения эксперимента, доказана безопасность высокочастотной электросварки мягких тканей в пределах температурных режимов от 45 до $95^{\circ} \mathrm{C}$ без явлений некроза и обугливания.

Ключевые слова: электросварка; физико-химические характеристики; биологические ткани; экспериментальные исследования; определение температуры.

Abstract

Objective. Investigation of physical properties of the biological tissues content and their role in process of electric welding of soft biological tissues, as well as the temperature measuring in the electric welding zone.

Materials and methods. Investigations were conducted, using created system for the temperature measuring, consisting of amplifier thermo-EDS, external module ACP E14-440 "L-Card", notebook with a program supply "PowerGraph". Bipolar electrosurgical clamp and $\mathrm{HF}$-electrocoagulator EK-300M1 were used as well. $\mathrm{K}$-type thermocouple $70 \mathrm{mcm}$ in diameter were selected for the temperatures diapason $40-200{ }^{\circ} \mathrm{C}$, occurring while performing of electric welding of biological tissues.

Results. The investigations conducted have permitted to establish, that resistance of electrolytes reduces and conductivity - enhances while temperature raised. It is explained by following: for mild solutions while temperature raises their dissociation enhances and, thus, as well - the positive and negative ions quantity. Electric conductivity of the whole organs is in $2-5$ times lower, than electroconductivity of biological liquids. That's why in «total» dehydration the tissue practically misses electroconductivity, heat in it ends to exude with abrupt fall in the current voltage, amperage and resistance occurs, preventing deep destructive changes in soft tissues in the electric welding zone. This data were obtained by us in a process of the experiment performance for studying of the temperature regimes in intestinal, muscular, pulmonary and hepatic tissues.

Conclusion. Security of a high frequency electric welding of soft tissues in spectrum of the temperature regimes from 45 to $95{ }^{\circ} \mathrm{C}$ without necrosis and charring was proved on background of data, obtained during the experiment.

Keywords: electric welding; physic-chemical characteristics; biological tissues; experimental investigations; measuring of temperature. 
За последние 15 - 20 лет технология электросваривания в медицине завоевала прочные позиции благодаря тканесохраняющему эффекту, незначительному деструктивному воздействию на живую ткань, что позволяет производить одномоментно разрез и коагуляцию практически без нарушения морфоструктуры ткани [1 - 4].

Вместе с тем остаются неизвестными многие особенности использования методики электросварки биологических тканей. До настоящего времени не выработаны конкретные рекомендации по применению режимов работы высокочастотного генератора ЕК-300M1, что требует проведения систематической работы по накоплению и упорядочиванию такой информации [3 - 5].

Мягкие биологические ткани являются композитными материалами с широким диапазоном свойств их составляющих. Они состоят из клеток, соединительной ткани и биологических жидкостей, которые в свою очередь состоят из фибриллярных и глобулярных белков, а также водных электролитов.

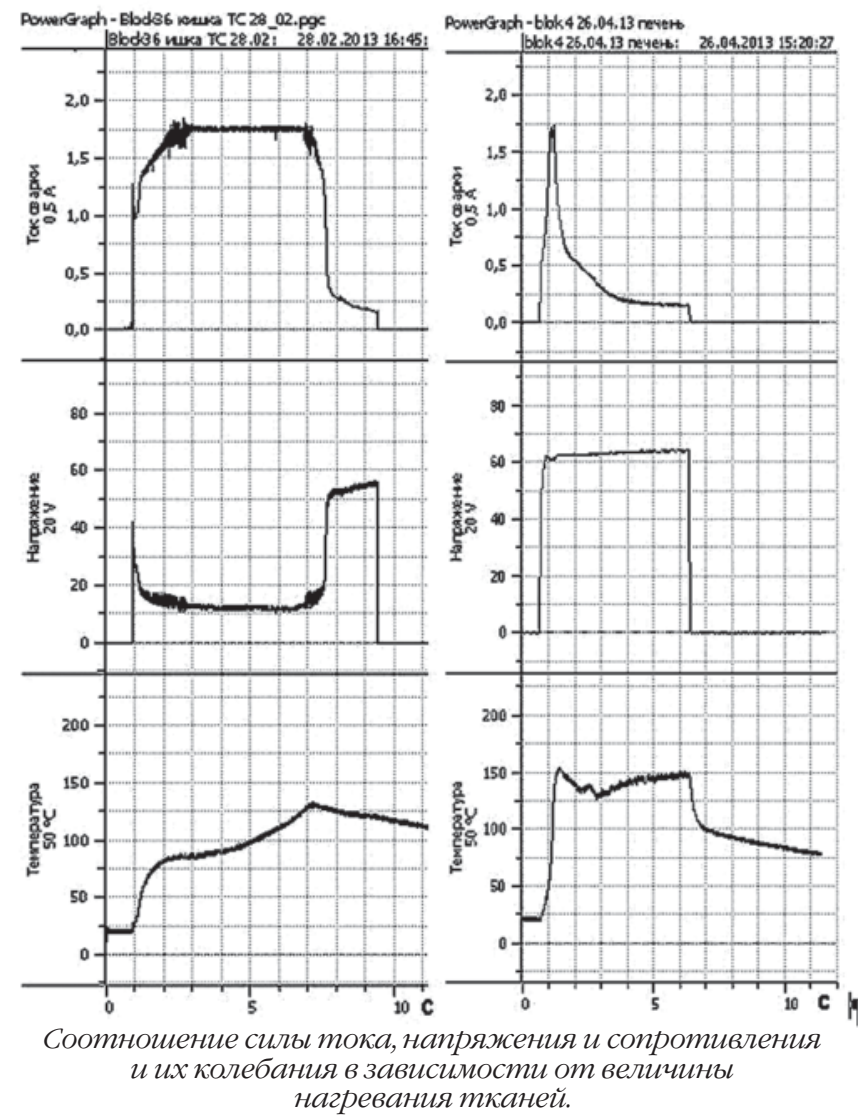

Для лучшего понимания процессов, происходящих при контактной сварке биологических тканей, желательно знать свойства и значение в этом процессе каждого композита.

Когда через ткань протекает электрический ток, в ней выделяется тепло, температура которого пропорциональна электрической мощности и времени протекания тока.

Таким образом, при высокочастотной сварке биологических тканей определяющим является их нагрев. Поэтому знание температуры ткани в формируемом сварном соединении при исследовании всех аспектов свар- ки чрезвычайно важно. Однако из-за трудностей измерения температуры сварного соединения в процессе сварки этот вопрос практически не изучен. Наряду с этим в научных докладах по электросварке живых мягких тканей различные авторы, игнорируя эти характеристики, указывают температуру в зоне сварки от 40 до $200{ }^{\circ} \mathrm{C}$ без достаточного обоснования приведенных данных.

Цель исследования: изучение физических свойств составляющих биологических тканей и их роли в процессе электрической сварки мягких биологических тканей, а также измерение температуры в зоне сваривания.

\section{Материалы и методы}

Основным технологическим параметром контактной сварки мягких биологических тканей является величина тока, протекающего через ткань. Электрическая проводимость биологических тканей определяется биологическими жидкостями (электролитами), содержащимися в тканях (внутриклеточная и внеклеточная жидкости, кровь, лимфа), которые составляют 86\% всей массы тела.

Экспериментальные исследования проведены на специально разработанном оборудовании путем физического моделирования в Институте электросварки имени Е. О. Патона НАН Украины под руководством доктора технических наук Ю. Н. Ланкина.

Для проведения исследований была создана система измерения температуры, состоящая из усилителя термоЭДС, внешнего модуля АЦП Е14-440 “Л-Кард”, ноутбука с программным обеспечением "PowerGraph". Использовался также биполярный электрохирургический зажим и ВЧ-электрокоагулятор ЕК-300М1. Поскольку при сварке биологических тканей диапазон температур составляет от 40 до 200 드, были выбраны термопары К-типа диаметром 70 мкм.

Термопару помещали между биологическими тканями в области прохождения тока биполярного сварочного инструмента.

Изучены температурные режимы мышечной ткани, тканей кишечника, легкого и печени.

\section{Результаты}

Результаты проведенных исследования представлены в виде графиков, которые отображают соотношение силы тока, напряжения и сопротивления и их колебания в зависимости от величины нагревания тканей (см. рисунок)

\section{Обсуждение}

Проведенные исследования позволили установить, что сопротивление электролитов уменьшается, а проводимость - увеличивается с повышением температуры. Это объясняется тем, что с повышением температуры для слабых растворов увеличивается их диссоциация и, следовательно, число положительных и отрицательных ионов. Наиболее выраженные токопроводящие свойства характерны для биологических внеклеточных жидкостей, основу которых составляют растворы электролитов. Прежде всего это кровь, содержащая 0,85\% раствор $\mathrm{NaCl}$ и в менышей концентрации соли других одновалентных и двухвалентных металлов. 
Сильное влияние на электропроводность биологических объектов оказывает содержание в них воды. В тканях с большим содержанием воды (от 70 до 80\% массы ткани - в легких, почках, печени, сердечной и скелетных мышцах) удельная электропроводность примерно на порядок выше.

При биполярной сварке биологических тканей в результате нагрева выделяется тепло в электропроводной биологической жидкости, являющейся электролитом, при прохождении через нее электрического тока. Твердые субстанции биологических тканей, окружающие биологические жидкости или находящиеся в них, не электропроводны, электрическим током не нагреваются и, следовательно, всегда холоднее жидкости.

Нормальная температура тела человека составляет 34 - $37^{\circ} \mathrm{C}$. Повышение температуры до $40^{\circ} \mathrm{C}$ не сопровождается ущербом для структурной целостности клеток и тканей. Однако когда температура клеток достигает $50{ }^{\circ} \mathrm{C}$, наступает их смерть приблизительно через 6 мин, а если температура повышается до $60{ }^{\circ} \mathrm{C}$, смерть клеток наступает мгновенно. В промежутке между 60 и $95^{\circ} \mathrm{C}$ (то есть ниже $100{ }^{\circ} \mathrm{C}$ ) происходит денатурация протеина, которую обычно называют «коагуляция» - результат процесса, подобного тому, который происходит с яичным белком при варке яйца вкрутую. Такое действие на ткани используют в электрохирургии для закрытия трубчатых структур или кровеносных сосудов с целью гемостаза. Если температура при электросварке повышается до 100 C или выше, внутриклеточная жидкость закипает с последующим массивным внутриклеточным расширением, что приводит к взрывчатому повреждению оболочек клетки, выпариванию жидкости с облаком пара.
Электропроводность цельных органов в 2 - 5 раз ниже, чем электропроводность биологических жидкостей. Поэтому при «полном» обезвоживании ткань практически теряет электропроводность, тепло в ней перестает выделяться и происходит резкое падение напряжения, силы тока и сопротивления, что предотвращает глубокие деструктивные изменения мягких тканей в зоне электросварки. Эти данные получены нами в процессе выполнения експеримента по изучению температурных режимов мышечной ткани, тканей кишечника, легкого и печени.

\section{Выводы}

Полученные в ходе експеримента данные доказывают безопасность высокочастотной электросварки мягких тканей в пределах температурных режимов от 45 до 95 ${ }^{\circ} \mathrm{C}$. Ткань сварного соединения денатурирована, полностью деструктурирована и представляет собой гомогенную массу коллагена, эластина и основных субстанций ткани с существенно уменьшенными границами между ними без явлений некроза и обугливания.

\section{References}

1. Ivanova ON, Paton BE, Lebedev VK. Perspektiva osvoenija novoj ne ogranichena. Medichinskij Vsesvit. 2004;4(1):166-72. [In Russian].

2. Muzychenko PF, Chernjak VA, Lankin JuN. Rol' jelektrohirurgii v razvitii mediciny. Klinichna hirurgiia. 2016;11(2):10-3. [In Russian].

3. Muzychenko PF, Chernjak VA, Lankin JuN. Istoricheskie aspekty i perspektivy jelektrohirurgii (Literaturnyj obzor). Ortopedija, travmatologija i protezirovanie. 2017;(1):124-7. [In Russian].

4. Paton BE. Jelektricheskaja svarka mjagkih tkanej v hirurgii. Avtomaticheskaja svarka. 2004;(9):7-11. [In Russian].

5. Swed OE, Podprjatov SE, Gupalo JuM. Jeksperimental'no obryntuvannja novyj metod gemostaza. Klinicheskaja jenciklopedija. 2008;(7):4954. [In Russian]. 